large amounts of excess virus coat protein in the form of spherical and tubular particles measuring $20-25 \mathrm{~nm}$ in diameter, and both viruses have $40-50 \mathrm{~nm}$ doubleshelled or solid particles with a nucleocapsid or core containing doublestranded circular DNA with a gap and a virus DNA polymerase, and show a high degree of antigenic cross-reactivity between the cores of the two viruses, and a small region of $100-150$ base pairs of nucleic acid homology as measured by liquid hybridization. The analogy between the two viruses is even closer when judged by their adaptation in their respective hosts causing persistent infection and close association with chronic liver disease and primary liver cancer.

Yet another virus related to human hepatitis B in Beechey ground squirrels (Spermophilus beecheyi) has been found in one region in northern California. Marion and her colleagues (Proc. natn. Acad. Sci. U.S.A. 177, 2941; 1980) identified a virus in these squirrels sharing many of the unique characteristics of the human virus. Common features include virus morpho- logy, size and structure of the viral DNA, a virion DNA polymerase which repairs a single-stranded region in the doublestranded circular genome, cross-reacting surface viral antigens, antigen-antibody systems similar to hepatitis $\mathrm{B} e$ antigen and the core antigen, and persistent infection with viral antigen present continuously in the blood. Because the ground squirrels were only bled and then released, it has not been possible to observe a disease accompanying this virus in the ground squirrel.

There is also some preliminary evidence suggesting further members of this unusual class of viruses in black-tailed prairie dogs (Cynons ludoviccianus) and in ducks in a province in the People's Republic of China. Virological studies, however, have not yet been completed.

As the human hepatitis B virus has not been grown in tissue culture, these phylogenetically related animal viruses may provide valuable models for the study of viral replication and the pathogenesis of chronic liver disease and primary liver cancer.

\title{
Hominoid habitats of the Miocene
}

\section{from Peter Andrews}

NEW STUDIES on the palaeoecology of fossil hominoids make it increasingly likely that fossil hominoids of the early Miocene, 18 to 20 million years ago, lived in quite different habitats from those of the middle Miocene, 12 to 15 million years ago, and suggest that the way of life of the ancestors of the great apes and man will have to be reconsidered. The early Miocene hominoid species are generally found associated with fossils indicating tropical forest conditions in contrast with the middle Miocene hominoids which are associated with temperate to tropical woodland. This ecological shift is accompanied by changes in tooth morphology - in particular the development of thick enamel - and in many other characters of the skull and postcrania. The early Miocene hominoids retain mainly primitive characters while the middle Miocene species have developed many more of the derived characters shared with the living great apes and man.

Hominoids in the middle Miocene were widely distributed in Europe and Asia along a broad belt stretching from southern Europe across to south-western China. Much of this region was covered with broad-leaved sclerophyllous woodland related to a vegetation type found today only in the Canary Islands (Axelrod Ann. Miss. Bot. Gard. 62, 280; 1975). The vegetation type was intermediate between

Peter Andrews is in the British Museum (Natural History), London. the tropical and subtropical forests to the south and the moist temperate woodlands with mixed conifers and broad-leaved trees to the north. It has not been clear to which part of this spectrum the middle Miocene hominoids were adapted, because direct associations betwen hominoid species and fossil floras have not, until recently, been available. Interpretations of past habitats by analysis of the animal faunas are limited, and at the Ramapithecus and Sivapithecus localities they do no more than indicate some type of woodland. However, a recently described flora from China that comes from the same beds as a mammalian fauna containing these hominoids provides the first direct evidence of the vegetation type associated with the middle Miocene thick enamelled apes.

The flora frum Lufeng, in south-western China, shows a succession up the fossiliferous sequence from a warm humid vegetation type to cool temperate types (Sun Xiang-jun and Wu Yu-shu Vert. Palas. 18, 255; 1980). The middle part of the sequence, which is where the hominoids occur, is a lignite containing pollen of both aquatic and land plants. The lignitic nature of the deposits and the presence of aquatic plants suggest swamp conditions but by far the most abundant plant forms are temperate trees and shrubs represented by 44 taxa, with 8 taxa of ferns, 11 of herbs, and 3 aquatic forms. The trees and shrubs consist of both evergreen and deciduous taxa, and the composition of the flora, although containing some sclerophyls, is closest to that of the temperate woodlands described by Axelrod as occurring to the north of the sclerophyllous belt during the middle Miocene. Woodlands of this type occur today in southern Europe to the north of the Mediterranean and Black seas. It is an unusual vegetation type in which to find primates, now largely tropical and subtropical in distribution and suggests that enamelled hominoids must have been able to survive in conditions beyond the range of most living primates.

Thick enamelled hominoids are known during the middle Miocene from Africa as well as from Europe and Asia. Faunas from Fort Ternan and Maboko Island, Kenya, have been analysed in another recent paper (Nesbit Evans et al. J. Hum. Evol. 10 (1), 1981), and demonstrate the presence of tropical woodland. The faunas have been analysed in two ways - by assessment of indicator species in the faunas, either singly or by combinations of species to produce habitat spectra, and by analysis of the community structure of the mammalian faunas through quantification of the diversity of ecological adaptations present in the faunas. The results of the two methods agree with each other, and with other evidence from the lower vertebrates and invertebrates, and assuming that the association between the hominoid species and the rest of the fauna is valid it can be inferred that the hominoids (Ramapithecus and/or Sivapithecus) also occupied woodland habitats during the middle Miocene in Africa.

The evidence for several early Miocene sites in Kenya is also reviewed in the same paper following the same methods. These confirm earlier results that at certain of the levels at Songhor, Rusinga Island and Koru, where the faunas are associated with hominoid species of the genera Proconsul, Limnopithecus and Dendropithecus, tropical forest habitat occurred.

The new data are of importance in considering the evolutionary emergence of the living great apes and man for they imply that their ancestors passed through an adaptive phase very different from their present way of life. Sivapithecus and Ramapithecus were the size of orang-utans and baboons respectively and animals of this size living in woodland habitats, whether tropical or temperate, must have been at least partly terrestial because of discontinuities in the woodland canopy. Again, because woodland habitat shows greater seasonal variation than forest the supply of fruit would have been insufficient to have played more than a minor role in the diet. In conclusion, many previous studies that have claimed an arboreal and frugivorous ancestry for the living great apes and man will need to be reconsidered, for the evidence from Middle Miocene suggests that hominoids of this period were omnivorous and partially terrestrial. 